\title{
Conceptual Difficulties Experienced by First-Year Undergraduate Chemistry Students in Assigning Oxidation Number: A Case Study of High School Chemistry Textbooks
}

\author{
Rahmat Basuki \\ Department of Chemistry, Faculty of Science and Technology, University of Jambi, \\ Jl. Jambi-Muara Bulian Km. 15, Mendalo, Jambi 36361, Indonesia
}

* Corresponding author:

tel: $+62-85743213964$

email:rhmtbsq@gmail.com

Received: July 4, 2018

Accepted: January 3, 2019

DOI: $10.22146 /$ ijc.36695

\begin{abstract}
The purpose of this research was to investigate first-year undergraduate chemistry students' understanding in assigning oxidation number following a case-study course instruction. A list of multiple choice question and interview section was formulated to identify the initial knowledge as representative of their conceptual understanding in assigning oxidation number obtained from their chemistry textbooks. This study revealed that most of 34 students who participated were confused about the nature of oxidation number. In the section of the interview which focused on applying "The Rules", many students experienced more problems in assigning oxidation number of sulfur in $\mathrm{S}_{2} \mathrm{O}_{3}{ }^{2-}$ ion. Several misconceptions relating to the inappropriate assumption in assigning oxidation number were identified. The data illustrated how students attempt to make sense of the concept obtained from High School with the knowledge they had already constructed in solve of a given question. The research implied that the teachers, lecturers, curriculum developers, and High School Chemistry textbooks authors need to be cognizant of the importance of related concept (electronegativity and dot-Lewis structure) with oxidation number. The high school and chemistry textbook authors were recommended to introduce this interconnection (including formal charge) to minimize the misconception and conceptual difficulties experienced by first-year undergraduate chemistry students in assigning oxidation number.
\end{abstract}

Keywords: conceptual difficulties; assigning oxidation number; misconception; case study of chemistry program students

\section{- INTRODUCTION}

During the past three decades, although there has been considerable research into students' understanding of chemistry, there has been relatively limited research focusing on undergraduates' understanding of chemistry concepts. Although there were studies carried out previously on primary and secondary students' understandings of chemistry, and teaching basic chemical concepts effectively [1-2], in recent years research has started to concentrate on undergraduates' (and prospective teachers') understanding of basic and advanced concepts in chemistry, such as chemical equilibrium [3], chemical kinetics [4], phase changes [5], vaporization, vapor pressure and vaporization rate [6-7], enthalpy [8], entropy [9-10], Gibbs free energy [11], chemical bonding [12], colligative properties [13] and also how to teach the concepts of chemistry effectively [14]. Overwhelmingly, evidence suggests that undergraduates' understanding of advanced ideas in chemistry is very poor because of lacks of basic concept understanding. Part of the difficulty rests with the nature of chemistry itself, but more seems to stem from how the concepts are customarily taught without regard to what is known about students' learning and the content structure of the domain [15].

The conceptual understanding of chemistry by students is an important issue. There are several concepts in chemistry at basic and advanced levels that are difficult to understand, because their operational definitions involve sophisticated reasoning [16]. The 
concepts of Oxidation Number (ON) are among those. Many students tend to memorize numerical equations or algorithms rather than learn the concepts. Therefore, they can solve numerical problems, but fail to answer conceptual questions. A review of the literature reveals that there are many misconceptions within the domain of chemistry [16-18]. The study of the oxidation-reduction concept has been a fundamental part of higher education chemistry courses for many years [19-20]. This topic includes the ON concepts, which seem to give high school students trouble because they involve abstract concepts. Assigning $\mathrm{ON}$ in high school was firstly taught in grade $\mathrm{X}$ after they learn chemical bonding, atomic theory, and the periodic table of elements. Mastery of the concepts associated with $\mathrm{ON}$ facilitates the mastery of these other chemical concepts. However, most of the commonly used high school chemistry textbooks perform only "The Rules" approach to assigning ON, without connecting with the previous chapter. Besides, the fundamental concept of determining ON was much related to the previous concept.

In the constructivist concept, whenever a concept has restricted meaning, this gives a false notion that concepts are single units. ON concept, in this case, should be differentiated in the mind of a person. As more and new relationships to other concept are acquired, the respective concepts take on new meaning [21]. Limited explanation of assigning ON only through "The Rules" will result in misleading interpretations or misconception [22]. Redox material misconception had been experienced by students, for example: they had a difficulty on distinguishing the definition of the oxygen and electrons transfer, they often experience an error in the determination of the oxidation number of atom in molecule. They did not know the key concept of oxidation and its relation to another concept, i.e. electronegativity; and related to that concept they had a difficulty on how to apply the equalization to the redox reactions [23]. Misleading interpretation on determining $\mathrm{ON}$ will affect the students in the understanding and application of redox concept.

Assigning ON study in high school studied in grade $\mathrm{X}$ for the first time, after they learn chemical bonding, atomic theory, and the periodic table of element. "The Rules" approach was the only method used in common high school chemistry textbooks in Indonesia. Simple molecules which have relatively higher electronegativity differences, such as, $\mathrm{HF}, \mathrm{H}_{2} \mathrm{~S}, \mathrm{H}_{2} \mathrm{SO}_{4}, \mathrm{PCl}_{3}$, and so forth, "The Rules" successfully worked. However, it has not given satisfying results when "The Rules" applied to a molecule with more covalent character which has fewer electronegativity differences $\mathrm{CH}_{3} \mathrm{COOH}, \mathrm{C}_{2} \mathrm{H}_{5} \mathrm{OH}$, $\mathrm{S}_{2} \mathrm{O}_{4}{ }^{2-}, \mathrm{POBr}_{3}, \mathrm{H}_{2} \mathrm{O}_{2}$, etc. It needed another related concept (dot-Lewis structure and electronegativity). Caused by this behavior of assigning ON using only "The Rule" in high school without mastering the fundamental concept of $\mathrm{ON}$, the student frequently experiences difficulties in learning concept relating the ON i.e. formal charge in university level. This research aims to explore the initial knowledge of assigning $\mathrm{ON}$ that student's brought from high school as represent of a chemistry textbook that they have learned. The research question answered in this study is: What misconceptions in initial knowledge - if any - about assigning oxidation number (ON) are found among first-year chemistry student in University of Jambi?

\section{- EXPERIMENTAL SECTION}

\section{Materials}

The material as a subject-sample of the study was 34 students of Chemistry Program in the first semester (2017/2018) of University of Jambi. They joined the Basic Chemistry I course subject. Based on constructivist principles of knowing by Von Glasersfeld (1995) knowledge is actively built up from within by a thinking person; knowledge is actively received through the senses or by any form of communication [24-27]. So, the new student was assumed to have initial knowledge of redox concept from their textbooks which actively communicated by the teacher in high school. It was also assumed that what they learn in high school represent by chemistry textbooks that they used [28-36].

\section{Instrumentation}

The research instruments were 15 multiple choice questions (Table 1) transformed from some common used 
Table 1. Fifteen (15) multiple choice questions as research instruments were transformed from some common used chemistry textbooks in Indonesia

\begin{tabular}{l}
\hline Name: \\
\hline High School chemistry mark: \\
\hline 1. Oxidation number of $\mathrm{N}_{\text {in }} \mathrm{HNO}_{3}$ \\
$\begin{array}{ll}\text { (a) }+5 & \text { Oxidation } \\
\text { (b) }+3 & \text { (a) } 0 \\
\text { (c) }+1 & \text { (b) }+3 \\
& \text { (c) }+5\end{array}$
\end{tabular}

2. Oxidation number of $\mathrm{Mn}$ in $\mathrm{KMnO}_{4}$
(a) +1
(b) +5
(c) +7

3. Oxidation number of both $\mathrm{Cr}$ in $\mathrm{K}_{2} \mathrm{Cr}_{2} \mathrm{O}_{7}$
(a) +3 and +3
(b) +6 and +6
(c) +12 and +12

10. Oxidation number of both $\mathrm{C}$ in $\mathrm{CH}_{3} \mathrm{COOH}$

4. Oxidation number of $\mathrm{O}$ in $\mathrm{KO}_{2}$
(a) -2
(b) -1
(c) $-1 / 2$

5. Oxidation number of $\mathrm{H}$ in $\mathrm{NaH}$
(a) -1
(b) 0
(c) +1
(a) 0
(b) +3
(c) +5
(a) -3 and +3
(b) -4 and +4
(c) 0 and 0

11. Oxidation number of $\mathrm{I}$ in $\mathrm{ICl}_{5}$
(a) +7
(b) +5
(c) 0

12. Formal Charge of both $\mathrm{S}$ in $\mathrm{S}_{2} \mathrm{O}_{3}{ }^{2-}$
(a) +2 and +2
(b) +5 and -1
(c) 0 and 0

13. Formal charge of $\mathrm{P}$ in $\mathrm{POBr}_{3}$

6. Oxidation number of $\mathrm{O}$ in $\mathrm{H}_{2} \mathrm{O}_{2}$
(a) -2
(b) -1
(c) +2

7. Oxidation number of $\mathrm{O}$ in $\mathrm{OF}_{2}$
(a) -2
(b) -1
(c) +2
(a) +7
(b) +5
(c) 0

14. Formal charge of both $\mathrm{C}$ in $\mathrm{CH}_{3} \mathrm{COOH}$
(a) -3 and +3
(b) -4 and +4
(c) 0 and 0

15. Formal charge of $\mathrm{I}$ in $\mathrm{ICl}_{5}$

8. Oxidation number of both $\mathrm{S}$ in $\mathrm{S}_{2} \mathrm{O}_{3}{ }^{2-}$
(a) +2 and +2
(b) +5 and -1
(c) 0 and 0

Note:

chemistry textbooks in Indonesia and a list of question for interview protocol (Table 2). Fifteen multiple choice problems were given in the test before entering the Redox Reaction chapter (pre-test) and then followed by an interview section.

\section{Procedure}

This research was conducted by descriptive analysis study with a form of case study research to address the research question and fulfill the purpose of the study. 


\section{Identification and validation of conceptual and propositional knowledge}

The procedure of the study was the students finish off the 15 multiple choice questions and then followed by individually interview section. This procedure designed to answer the purpose of the study involved the identification of conceptual and propositional knowledge about what they know. After the completion of each question, students reflect on the abstract knowledge gained [37]. This stage can be used by an instructor (lecturer) as a foothold to give additional knowledge which is necessary for students to fully understand oxidation number and related concept. Several senior high school chemistry textbooks were examined to formulate 15 multiple choice questions. The questions were reviewed by an expert in chemistry education and a high school chemistry teacher. Their comments were used to revise the original list of problems. The purposes for undertaking this task were threefold. First, the problems provided a scientifically accurate body of knowledge so that student's responses could be compared with scientifically accurate views. Second, the problems provide a complete and comprehensive list of the knowledge required by students to understand oxidation number concept. Third, the problem provided the framework for the development of the interview protocol and data analysis procedure.

\section{Development of the interview protocol}

The purpose of the interview was to explore a sample of students' understandings of oxidation number concept and identify any difficulties or misconception in initial knowledge. The questions of interview protocol
(Table 2) were not limited and may be expanded depending on the necessity. A semi-constructed interview protocol was developed based on the list of 15 multiple choice questions as conceptual and propositional knowledge. The interview process was carried out individually directly after the students finish off 15 multiple choice questions.

\section{Sample size and selection}

Thirty-four new chemistry students in first academic year 2018/2019 in University of Jambi have been asked to solve 15 multiple choice questions based on their knowledge before entering The Redox Reaction chapter in Basic Chemistry I course (pre-test). The students were classified into top, medium and bottom rank in class based on their mark in high school and author's objective observation. This classification aims to strengthen the representation of students' responses. The answer given by the students was assumed as a reflection of their thinking ability and their understanding on the previous concept that has been learned (in high school). The result was then discussed how the students respond to clarify the reason for their answers through interview section.

\section{Analysis of data}

The interviews were recorded on digital audio and analyzed within a few days of the event. The tapes were played twice, and each student's responses were summarized question by question. The dialogue was then classified based on the similarity respond. The selected dialogue was transcribed verbatim from the record and represented into a short conversation. The classified students' response is presented in Table 3.

Table 2. List of question for interview protocol

1. What "tools" do you use to assign the ON?

2. How do you assign ON of molecule in the question? Show the explanation.

3. Where did you have "The Rules" to assign ON? If it is from chemistry textbooks, mention the title/author/publisher.

4. Is any other "tools" to assign the ON beside "The Rules"?

5. Is the association of two atoms or more always have same $\mathrm{ON}$ each atom?

6. How do you confirm that the $\mathrm{ON}$ of each atom was correct?

7. Do you know that $\mathrm{ON}$ has assign based on its Lewis structure and electronegativity?

8. Do you know Formal Charge? 
Table 3. Summary of the students' responses results to interview section

\begin{tabular}{|c|c|c|}
\hline Student & Position in Class ${ }^{\star}$ & Students' Response \\
\hline Herman & Middle & $\begin{array}{l}\mathrm{ON} \text { of } \mathrm{Cr} \text { in } \mathrm{K}_{2} \mathrm{Cr}_{2} \mathrm{O}_{7} \text { was }+12 \text {. Doubt the } \mathrm{ON} \text { is }+12 \text { or must divide }+12 \text { by } 2 \\
\text { because the amount of } \mathrm{Cr} \text { is } 2 \text {. (Doubt about } \mathrm{ON} \text { was for on atom or group of } \\
\text { atoms). }\end{array}$ \\
\hline Gita & Bottom & Confused $\mathrm{ON}$ of chromium atom in $\mathrm{K}_{2} \mathrm{Cr}_{2} \mathrm{O}_{7}$ was +12 or +6 \\
\hline Rawel & Top & ON always an average of total ON of group atom divided by its subscript \\
\hline Reza & Top & $\begin{array}{l}\text { Know that } \mathrm{KO}_{2} \text { was superoxide, so the } \mathrm{ON} \text { of } \mathrm{O} \text { was }-1 / 2 \text { (Should know the } \\
\text { exceptional atom first, other ON will follow). }\end{array}$ \\
\hline Dea & Bottom & $\begin{array}{l}\text { Confused what should assign first, } \mathrm{O} \text { or } \mathrm{K} \text { in } \mathrm{KO}_{2} \text { and } \mathrm{Na} \text { or } \mathrm{H} \text { in } \mathrm{NaH} \text {, didn't } \\
\text { familiar the exceptional. }\end{array}$ \\
\hline Kiranti & Top & Never learn before that $\mathrm{ON}$ of atom in molecule was related to its Lewis structure. \\
\hline
\end{tabular}

${ }^{\star}$ Students were designated as being in the top, middle, or bottom third of their class

Summaries such as these were examined for common and disparate replies and were used to identify students' misconceptions. Clearly, responses from Herman, Gita, Rawel, Reza, Dea, and Kiranti revealed confusion about the nature of $\mathrm{ON}$ and related concept (electronegativity and dot-Lewis structure). Quotes from them presented in the results section and added support to the documentation of students' misconceptions about assigning ON. Interpretations made from the summaries were confirmed or rejected by referring to individual student summaries and the audio record. This procedure was carried out twice by the author to ensure reliability.

\section{- RESULTS AND DISCUSSION}

In this article, the discussion of the results focused on two areas of student's difficulties: assigning ON by using "The Rules" and correlation ON with related concept (dot-Lewis structure and electronegativity). These difficulties give rise to misconceptions which are discussed below. The results of students' answer in 15 multiple choices question presented in Fig. 1.

\section{Assigning Oxidation Number}

In response to question 1, all students successfully gave the correct answer and explain well how they got $\mathrm{ON}$ of nitrogen atom in $\mathrm{HNO}_{3}$ using "The Rule". As stated before, common used high school chemistry textbooks use the "Rules" to determining ON. Here is the summary of these "Rules" from commonly used high school chemistry textbooks [28-36]: (1) ON of free atom is zero; (2) ON of metal always has a positive sign. For example, $\mathrm{ON}$ of primary group $(\mathrm{A})$ should be determined

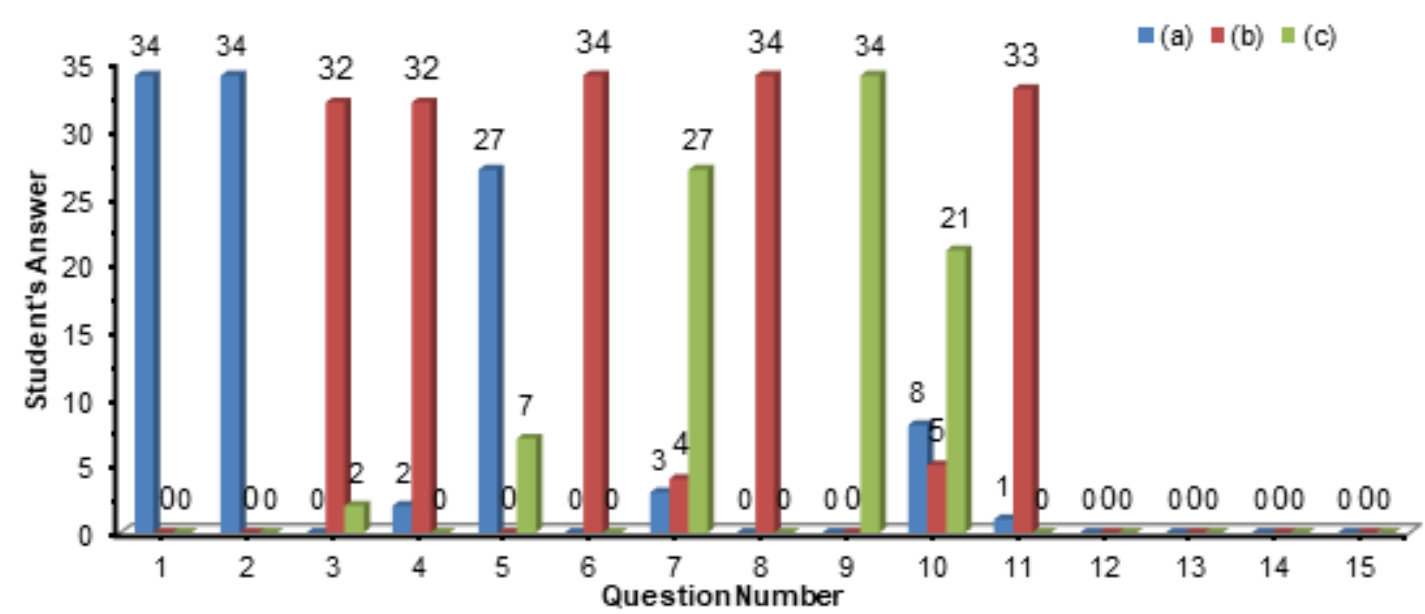

Fig 1. Students' answer results of 15 multiple choice questions as representation of common high school textbooks which was given before entering the Redox Reaction chapter (pre-test) 
from its group, such as group IA generally is +1 , IIA is +2 , IIIA is +3 , VIIA generally is -1 , and so forth. Metal of transition group has varied value of $\mathrm{ON}$, such as Fe: +2 and +3 , Cu: +1 and +2 , and so forth (3) Sum of ON in neutral molecule is zero; (4) $\mathrm{ON}$ of monoatomic ion is equal to its charge; (5) Sum of ON in polyatomic ion is equal to its charge; (6) ON of oxygen atom is commonly 2 , but it is -1 in peroxide, and $-1 / 2$ in superoxide; (7) ON of hydrogen atom is commonly +1 , but it is -1 in hydride; and (7) $\mathrm{ON}$ of another atom, determined from its group, such as group IA generally is +1 , IIA is +2 , IIIA is +3 , VIIA generally is -1 etc.

It is mentioned in these textbooks [28-36], how to determine $\mathrm{ON}$ of nitrogen atom in $\mathrm{HNO}_{3}$ as shown by the students using rule number (2), (5), and (6), the calculation can be expressed:

$(1 \times \mathrm{ON}$ of $\mathrm{H})+(1 \times \mathrm{ON}$ of $\mathrm{N})+(2 \times \mathrm{ON}$ of $\mathrm{O})=0$

$(1 \times+1)+(\mathrm{ON}$ of $\mathrm{N})+(3 \times-2)=0$

$(+1)+\mathrm{ON}$ of $\mathrm{N}+(-6)=0$

$\mathrm{ON}$ of $\mathrm{N}=+5$

The other examples that can be solved using "The Rules" were a question no. 2: $\mathrm{KMnO}_{4}$, and another molecule, such as $\mathrm{NaCl}, \mathrm{H}_{3} \underline{\mathrm{P}} \mathrm{O}_{4}, \underline{\mathrm{S}} \mathrm{O}_{3}$, and so forth (the underlined atom was atom would be determined its $\mathrm{ON}$ ). The simpler method represents "The Rule" can be seen in Fig. 2. These results indicate the good understanding of some simple molecule that it's ON can be solved only by "The Rules".

Misconception 1: ON belongs to a group of the atom.

Misconception 2: ON of atom in group's atom is always average of total $\mathrm{ON}$ of group atom divided by the subscript of that group atom.

Based on the author's experience, misconception 1 frequently was experienced by many students. In response to question 3, Herman and Gita got the wrong answer caused by mistake assumption that $\mathrm{ON}$ belong to a group of atom:

Interviewer: Show me, how did you assigning $\mathrm{ON} \mathrm{Cr}$ in $\mathrm{K}_{2} \mathrm{Cr}_{2} \mathrm{O}_{7}$.

Herman : (explain how he got $\mathrm{ON}$ by using methods in Fig. 2 as a representation of "The Rules")

Interviewer: So, the $\mathrm{ON}$ of $\mathrm{Cr}$ in $\mathrm{K}_{2} \mathrm{Cr}_{2} \mathrm{O}_{7}$ is +12 or +6 ?

Herman : I think it is +12 . Actually, I doubt the $\mathrm{ON}$ is +12 or we must divide +12 by 2 because the amount of $\mathrm{Cr}$ is 2 .

Two students (Herman and Gita) was answered +12 (option $\mathrm{c}$ in question 2) for $\mathrm{ON}$ of chromium in $\mathrm{K}_{2} \mathrm{Cr}_{2} \mathrm{O}_{7}$. Gita has referred the similar answer with Herman. They confused $\mathrm{ON}$ of chromium atom in $\mathrm{K}_{2} \mathrm{Cr}_{2} \mathrm{O}_{7}$ was +12 or +6 . The right concept was that $\mathrm{ON}$ belongs to the only single atom. So, +12 should be for the two atoms of chromium because the subscript represents the amount of an atom in one molecule.

Misconception 2 was experienced almost in all high school students. Rawel is one of an outstanding student in Basic Chemistry class and based on the author's observation and his chemistry mark in high school, Rawel was ranked in the top of the class. He correctly stated that ON belongs to one atom, but experienced conceptual conflict when trying to explain the $\mathrm{ON}$ of each atom in a group of atom:

\begin{tabular}{|c|c|c|c|}
\hline $\begin{array}{l}\text { ON Each } \\
\text { Atom } \\
\text { Amount ON } \\
\text { of neutral molecule } \\
\text { should be zero }\end{array}$ & $\begin{array}{c}+1+5-2 \\
\mathrm{HNO}_{3}^{+1+5-6}=0 \\
\text { Amount on } \\
\text { of same atoms }\end{array}$ & $\begin{array}{c}\text { ON Each } \\
\text { Atom } \\
\text { Amount ON ofion } \\
\text { should be the charge }\end{array}$ & $\begin{array}{c}\mathrm{PO}_{4}{ }^{3-5-2} \\
+5+8=-3 \\
4 \\
\text { om same on } \\
\text { of same atoms }\end{array}$ \\
\hline${ }^{+1} \mathrm{Na} \underline{-1}$ & $\stackrel{+6}{\mathrm{~S}}_{3}^{-2}$ & $\begin{array}{l}+1+7-2 \\
\mathrm{KMnO}_{4}\end{array}$ & $\mathrm{SO}_{4}{ }^{2-}$ \\
\hline$+1 \overline{-1}=0$ & $+6-6=0$ & $+1+7+8=0$ & $+6+8=-2$ \\
\hline
\end{tabular}

Fig 2. Sketch of simplification methods to assigning $\mathrm{ON}$ as "The Rule" representation applies in common molecules/ions 
Interviewer: are you sure the $\mathrm{ON}$ of both $\mathrm{Cr}$ in $\mathrm{K}_{2} \mathrm{Cr}_{2} \mathrm{O}_{7}$ was +6 ?

Rawel : Yes, I am. Because one atom has one value of ON.

Interviewer : Is the $\mathrm{ON}$ always an average of total $\mathrm{ON}$ of group atom divided by its subscript?

Rawel : Yes, I am. Initially, I was pretty much sure. But, after I saw the answer option, I hesitate that it is always the average. I do not know. I never been taught this in high school.

The student's answers on question 1-3 proved that using only "The Rules" was worked for certain molecules (most of simple molecule). The misconception was rise from inadequate knowledge of redox concept. The misconception might cause by the high school chemistry textbooks was not provide additional explanation besides "The Rules" and teacher was not emphasize this section [38-39].

\section{The ON of Exceptional Atom}

\section{Misconception 3: The exceptional atom has to be known first, and then $\mathrm{ON}$ will follow}

Rule number (5) and (6) stated that there was any exceptional $\mathrm{ON}$ for hydride (-1), peroxide (-1), and superoxide (-1/2). A misconception emerged when students try to solve question 4-7. In fact, question 4 still can be solved only using "The Rule". Thirty-two (32) students who have the correct the answers mostly stated that alkaline group (IA group) must have $\mathrm{ON}=+1$ (IA group only have $\mathrm{ON}=+1$ ) and the other atom (oxygen) will follow. So based on "The Rules", the correct answers were $\mathrm{ON}$ of $\mathrm{K}=+1$, and $\mathrm{O}=-1 / 2$. The confusing the rest of them (Dea and Bella) was what atom was to be determined first. Dea achieved low rank in class, and she also answered +1 (option C) in question 5. In the following dialogue she revealed that she did not regard the exceptional $\mathrm{O}$ and $\mathrm{H}$ :

Interviewer: Why did you choose -2 (option A) for oxygen atom in $\mathrm{KO} 2$ ?

Dea $\quad$ : I did not know. I have confused what should assign first, $\mathrm{O}$ or $\mathrm{K}$.

Interviewer: For question 5, NaH you did the wrong answer too. Why you finally choose that answer?
Dea $\quad$ : I only familiar with ON H: +1 and ON O: 2.

The interview with Reza, whose get top rank in class, supports misconception 3:

Interviewer: Why did you choose $-1 / 2$ (option $\mathrm{C}$ ) for oxygen atom in $\mathrm{K}_{2} \mathrm{O}$ ?

Reza : Because I know it was peroxide. Beside, $\mathrm{K}$ only has $\mathrm{ON}+1$.

Interviewer: You did the same method to $\mathrm{NaH}$ and $\mathrm{H}_{2} \mathrm{O}_{2}$ ?

Reza :Yes, I did.

Interviewer: Could you explain, why the $\mathrm{ON} O$ of peroxide is -1 , peroxide $-1 / 2$, and $\mathrm{H}$ in hydride is -1 ?

Reza $:$ Hmmm... I do not know why. I think it is exceptional.

In question 7, 27 students choose the correct answer, and the rest split to option A (3 students) and B (4 students). But, most of them were confused to assign $\mathrm{ON}$ of each atom especially its sign, (+) or (-). Even though almost $80 \%$ of students gave the correct answers, but they were just guessing. They were doubtful because they have no fundamental concept to confirm their results. It is evident in answering question 7 that they cannot give a precise reason why they choose the answer. Most of them answered "The Rules" without any explanation because they have no knowledge other than "The Rules". Some students responded it was "exceptional", when they asked why. But still, they didn't know for sure when using "The Rules" as an exceptional and common one. Only two students, Rawel and Reza which state "It was because $F$ located after right $O$, so the $O N F$ is -1 and $O$ is +2 ". But they did not mention the electronegativity. Based on the work of Garnett and Treagust [40], this phenomenon was common since in High School, and several misconceptions related to the inappropriate use of definitions of oxidation and reduction were identified.

Question 4-7 shows us that $\mathrm{ON}$ is strongly related with other concepts. The concepts that so related with ON were electronegativity and dot-Lewis structure. The definition by its terminology of $\mathrm{ON}$ is the charge remaining on an atom when all ligands are removed 
heterolytically in their closed form, with the electron being transferred to the more electronegative partners; homonuclear bonds do not contribute to the ON [41]. On the other hand, for a formal charge (FC), in any combining two or more different atoms, it is assumed that there is always full equally sharing of electrons between the two atoms. Fig. 3 shows the explanation of where the ON was known based on electronegativity by Pauling scale (Table 4) on several selected atom [42].

For this superoxide case, three electrons should be in sharing between the two oxygen atoms in $\mathrm{O}_{2}{ }^{-}$as bonding electrons and it is impossible to break this bond heterolytically for exactly the same atoms $(\mathrm{O})$, but it is also impossible to break homolytically an odd number of electrons. Basically ON and FC is "imaginary numeric value" because it could not break one electron to be in a $1 / 2$.

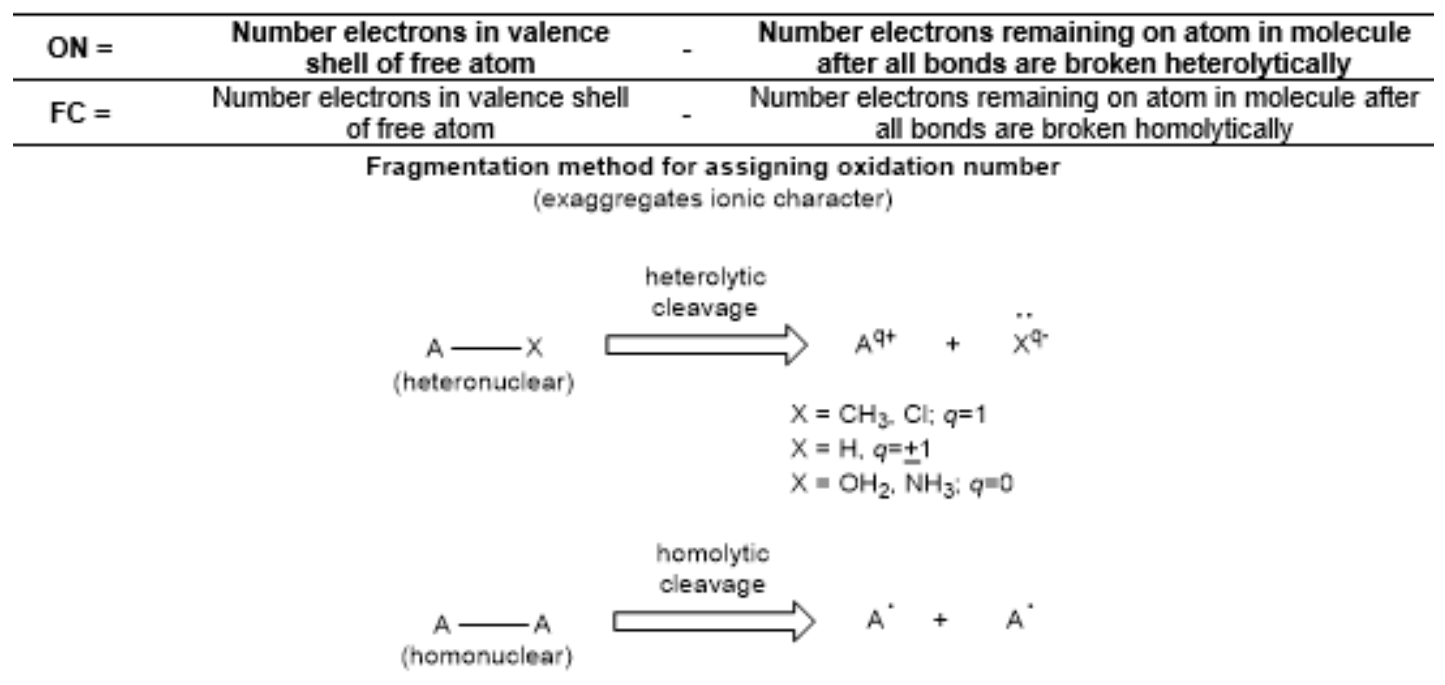

Fragmentation method for assigning formal charges

(exaggregates ionic character)

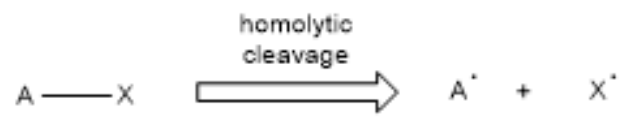

Fig 3. The differences between fragmentation methods for assigning oxidation number (ON) and formal charge (FC)

Table 4. Electronegativity of Pauling Scale several selected atoms [36]

\begin{tabular}{lllllllll}
\hline 1 & 2 & 12 & 13 & 14 & 15 & 16 & 17 & 18 \\
\hline $\mathrm{H}$ & & & & & & & & $\mathrm{He}$ \\
2.300 & & & & & & & & 4.160 \\
$\mathrm{Li}$ & $\mathrm{Be}$ & & $\mathrm{B}$ & $\mathrm{C}$ & $\mathrm{N}$ & $\mathrm{O}$ & $\mathrm{F}$ & $\mathrm{Ne}$ \\
0.912 & 1.576 & & 2.051 & 2.554 & 3.066 & 3.610 & 4.193 & 4.787 \\
$\mathrm{Na}$ & $\mathrm{Mg}$ & & $\mathrm{Al}$ & $\mathrm{Si}$ & $\mathrm{P}$ & $\mathrm{S}$ & $\mathrm{Cl}$ & $\mathrm{Ar}$ \\
0.869 & 1.293 & & 1.613 & 1.916 & 2.253 & 2.589 & 2.689 & 3.242 \\
$\mathrm{~K}$ & $\mathrm{Ca}$ & $\mathrm{Zn}$ & $\mathrm{Ga}$ & $\mathrm{Ge}$ & $\mathrm{As}$ & $\mathrm{Se}$ & $\mathrm{Br}$ & $\mathrm{Kr}$ \\
0.734 & 1.034 & 1.588 & 1.756 & 1.994 & 2.211 & 2.424 & 2.685 & 2.966 \\
$\mathrm{Rb}$ & $\mathrm{Sr}$ & $\mathrm{Cd}$ & $\mathrm{In}$ & $\mathrm{Sn}$ & $\mathrm{Sb}$ & $\mathrm{Te}$ & $\mathrm{I}$ & $\mathrm{Xe}$ \\
0.706 & 0.963 & 1.521 & 1.656 & 1.824 & 1.984 & 2.158 & 2.359 & 2.582 \\
$\mathrm{Cs}$ & $\mathrm{Ba}$ & $\mathrm{Hg}$ & $\mathrm{Tl}$ & $\mathrm{Pb}$ & $\mathrm{Bi}$ & $\mathrm{Po}$ & $\mathrm{At}$ & $\mathrm{Rn}$ \\
0.659 & 0.881 & 1.765 & 1.789 & 1.854 & $(2.01)$ & $(2.19)$ & $(2.39)$ & $(2.60)$ \\
\hline
\end{tabular}


There is no choice besides using an average of $\mathrm{ON}$ even in this odd number of electron. Even though, there was no different result in ON value conducted by both only "The Rules" and sketch dot-Lewis structure. However, using sketch dot-Lewis structure term of "imaginary numeric value" seems logical and can be explained clearly to the students. The chemistry students should reach this level of understanding in $\mathrm{ON}$ and $\mathrm{FC}$ concept.

\section{The Correlation of ON, Lewis Structure and Electronegativity}

Based on the sketch of redox definition as presented in Fig. 3, two things could be concluded: (1) ON can be determined from differences between electronegativity values. "The Rules" is a simplification of concept to assigning $\mathrm{ON}$, and it is really powerful to assign $\mathrm{ON}$ of simple molecule. However, uses of "The Rule" should be completed by related concept because of the nature of $\mathrm{ON}$ was differences of electronegativity values [43]. The amounts of differences of electronegativity lead to the type of chemical bonds, if it were high, the substance tend to ionic, otherwise if slight, it tends to covalent. (2) ON concept is designated for a substance that has any -even a little- electronegative differences (bonding between different atoms), so the substance assumed tends to ionic. However, it was also could be applied to the covalent substance as long as they have any electronegative differences. These electronegative differences cause the heterolytic cleavage, where electron will move to atom with greater electronegativity. If the atom in substance has the same electronegativity, so the substance tends to be covalent and cause the homolytic cleavage, where the electron will be shared equally to each atom/ligands. This condition obtains a new unit called formal charge (FC).

In response to question 8 , all of 34 students answer option A. This response revealed that they assume the $\mathrm{ON}$ of an atom in the group of atom was always the average value. This assumption express as misconception 2 . The Interview with Kiranti, whose chemistry result was best in class, supports misconception 2:

Interviewer: How about question 8 , what $\mathrm{ON}$ of both $\mathrm{S}$ in $\mathrm{S}_{2} \mathrm{O}_{3}{ }^{2-}$ ?
Kiranti : My answer is A (+2 and +2$)$. But now, I was querying my answer. I do not know, I think there was another method to solve it.

Interviewer: The correct answer was $\mathrm{B},+5$ and -1 .

Kiranti :(shocked)... How it was possible?!

Interviewer: Did you know that $\mathrm{ON}$ of atom in molecule was related to its Lewis structure?

Kiranti : I did not know. I never learned it in high school, even in Olympiad class. I just found out.

Assigning $\mathrm{ON}$ based on this concept requires drawing the dot-Lewis structure (electron-dot) that molecule. Whereas, electron in covalent polar bond is not fully shared, to simplify the ON calculation it is assumed that an electron "is fully transferred to" atom with greater electronegativity. Example assigning $\mathrm{ON}$ of varied chlorine atom (Fig. 4) explains that is why the sum of $\mathrm{ON}$ of free molecule has zero. Chlorine atom in $\mathrm{Cl}_{2}$ molecule has the same electronegativity, so it will have homolytically cleavage, where electron shared equally. So, $\mathrm{ON}$ of both $\mathrm{Cl}$ atoms can be counted as 7 $7=0$. The same principle can be applied to Fig. 5 that electron as if "belong to" the more electronegative atom. Uses only "The Rule" will fail to assign the correct value of $\mathrm{ON}$ in question 8. They need a related concept: electronegativity and dot-Lewis structure. These concepts must be mastered well to avoid the misconception. Therefore, insufficiency of any concept and its related concept will lead to misconception $[22,44]$.

The entire students in this study think that $\mathrm{ON}$ of sulfur atom in $\mathrm{S}_{2} \mathrm{O}_{3}{ }^{2-}$ ion has the same value, +2 . Using only "The Rules" they used to calculate $2 \times(\mathrm{ON} \mathrm{S})+2 \times$ $(-2)=-2$. It was reasonable because they did not know if dot-Lewis structure will assign the $\mathrm{ON}$ value. They confess that they never been taught in High School to assign ON through drawing the dot-Lewis structure first. So the students might only think the ON was always average. So, using only "The Rule" for particular molecule -usually called exceptional, as long as they knew that it was exceptional- will lead to wrong ON value. Without drawing dot-Lewis structure, this calculation cannot be accepted because each of sulfur has 


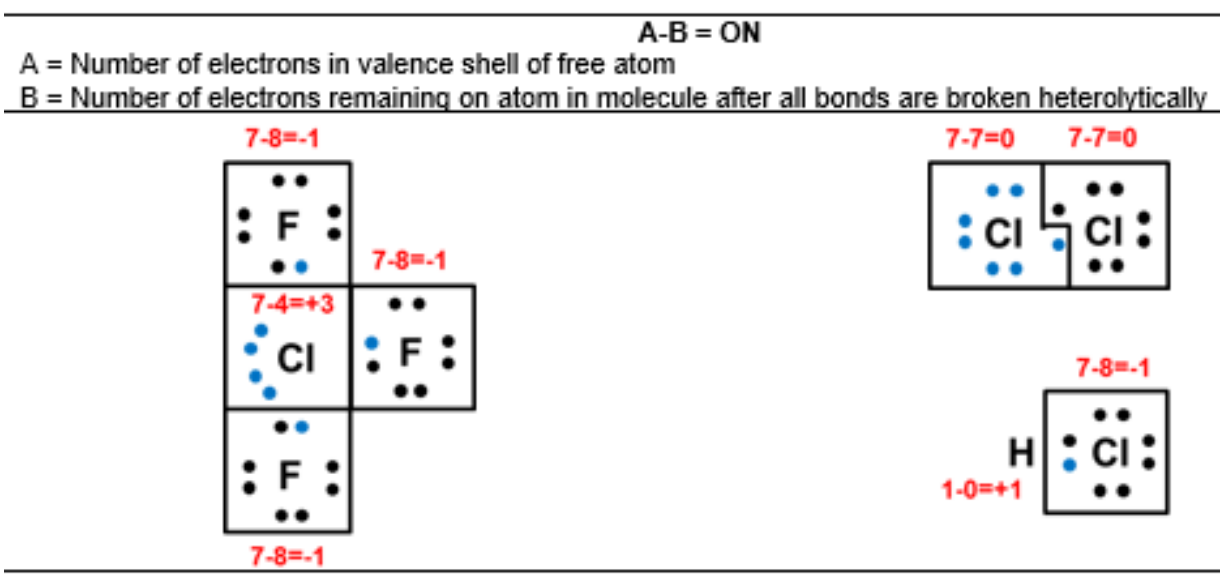

Fig 4. Assigning $\mathrm{ON}$ of varied chlorine atom that electron(s) were always fully transfer from atom having less electronegative to that more electronegative

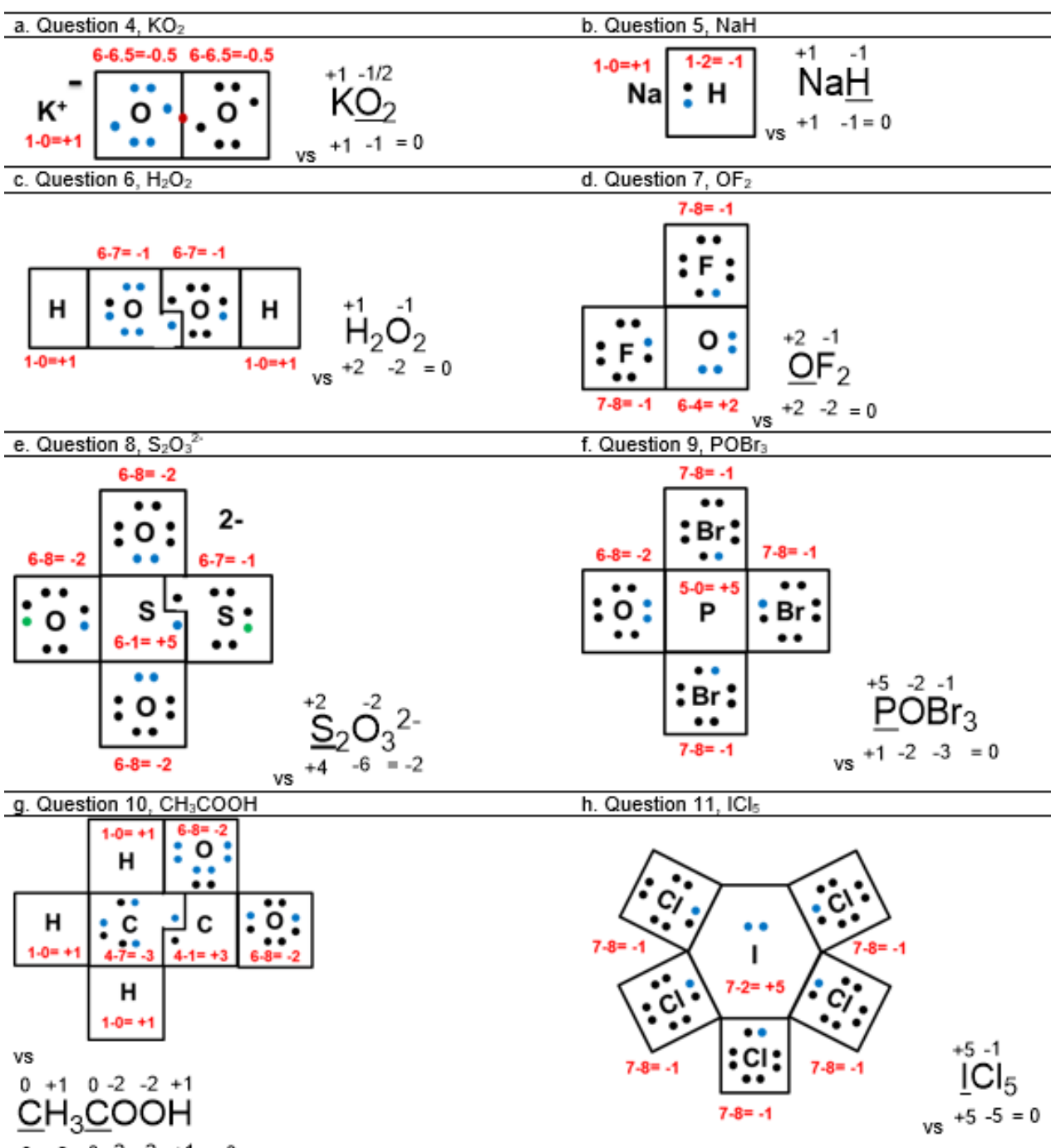

Fig 5. Assigning ON by electron(s) were always fully transfer from atom having less electronegative to that more electronegative vs. only "The Rules” of Question 4-11 
different environment. ON of $S$ (center) has only 1 electron left because it is bonding with 3 oxygen atoms which have higher electronegativity than $S$ and $1 \mathrm{~S}$ atom which have equal electronegativity. So, calculation can be written ON S (center) $=6-1=+5$, for $\mathrm{S}$ (side) $\mathrm{ON}=6-$ $7=-1$. ON of atom in group's atom was not always average of total $\mathrm{ON}$ of group atom divided by the subscript of that group atom. Assigning $\mathrm{ON}$ of question 4-11 can be seen in Fig. 5.

\section{The Correlation of ON and Formal Charge (FC)}

All of 34 students in this study coincide to response "Just heard that term, never learn formal charge (FC) in high school" for question 12-15. The response was normal because FC does not exist in the high school chemistry syllabus. However, chemistry teacher/textbooks may introduce the nature of $\mathrm{ON}$ and related concept so that the formal charge term will familiar to students. The lack of this knowledge will be one of the reasons why many students at all levels struggle to learn chemistry, but they are often unsuccessful. Discovering the concept and its connection with another concept has been the target of many studies. One possible answer that is beginning to emerge is that many students cannot construct appropriate understandings of fundamental chemical concepts from the very beginning of their studies caused by there is no further explanation about the related concept from textbooks/teachers. Therefore, they cannot fully understand the more advanced concepts that build upon the fundamentals [45].

The difference of fundamental approach between ON and FC has an important perspective: ON is constant, and it is not dependent on resonance structure, unchanged even the dot-Lewis structure was changed (resonance). But FC is changed depending on its resonance structure. The example of this phenomenon can be seen in resonance of thiocyanate ion (Fig. 6). Applying only "The Rules" to assigning ON was not so helpful if dealing with a group of atom in the molecule. It was only can be solved with the combination of dot-Lewis structure and electronegativity. According to interviewed students, the most used high school chemistry textbooks among the 9 textbooks [28-36] was authored by Purba and

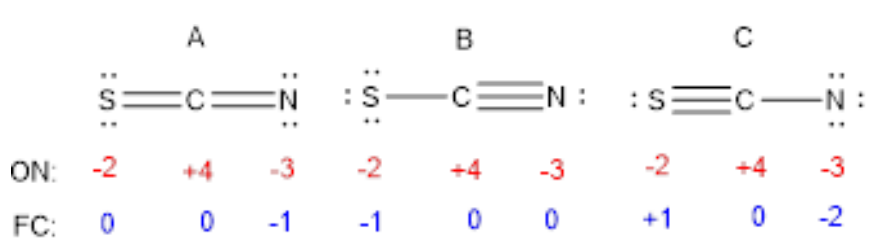

Fig 6. $\mathrm{ON}$ and $\mathrm{FC}$ of thiocyanate ion resonance. $\mathrm{FC}$ was changed analogously with resonance changing but $\mathrm{ON}$ was not

Sarwiyati [34]. These textbooks were also the only one from 9 textbooks that provide the information of electronegativity role in assigning $\mathrm{ON}$ even in a limited way. But still, there was some mistake in a molecule as an example of these textbooks [28-36]. Sketch of assigning ON by only "The Rules" versus by the dotLewis structure and electronegativity of these molecules presented in Fig. 6. Because of the interconnection among related concept is very important, the connection between related concepts to ON should be taught in the beginning of High School and deepened in University. The high school chemistry textbooks are better to provide enrichment matter/additional information about this. Besides, the chemistry instructor/teacher/ lecturer is often neglecting to emphasize the importance of this relation [46-47]. From a constructivist perspective, students and instructor/teacher/lecturer must consider this related concept in redox as they become engaged in the subject of chemistry.

\section{- CONCLUSION}

"The Rules" is a powerful method to assigning ON. However, used only "The Rules" have any limitation. "The Rules" should be completed with a related concept to nature of oxidation number: electronegativity and dot-Lewis structure. This study concluded that most of students only know "The Rules" to assigning $\mathrm{ON}$ as initial knowledge from High School because their chemistry textbook was not completed by additional information related $\mathrm{ON}$ concept. Additionally, the chemistry instructors/teacher/lecturer was often negligent to emphasize the importance of this relation. This condition was vulnerable to lead the misconception of ON in particular molecule as identified in this study. As a suggestion, the instructors/teacher/lecturer must 
consider this related concept in redox as they become engaged in the subject of chemistry. Learning ON in High School (or in the beginning year in university) should be taught by a related concept: electronegativity and dotLewis structure supported by chemistry textbook containing complete related concept. Without learning these connection concepts, misconceptions tend to occur, and the student will struggle to learn chemistry. The publisher/textbook author's was also considering this to revise the book.

\section{- ACKNOWLEDGMENTS}

The author thanks Dr. Madyawati Latief and Dr. Ngatijo to facilitate this research; Dr. Yusnaidar and Netri Mardia, S.Pd. for the review and validating the research instrument.

\section{- REFERENCES}

[1] Tytler, R., 2000, A comparison of year 1 and year 6 students' conceptions of evaporation and condensation: Dimensions of conceptual progression, Int. J. Sci. Educ., 22 (5), 447-467.

[2] Zikovelis, V., and Tsaparlis, G., 2006, Explicit teaching of problem categorisation and a preliminary study of its effect on student performance - the case of problems in colligative properties of ideal solutions, Chem. Educ. Res. Pract., 7 (2), 114-130.

[3] Van Driel, J.H., 2002, Students' corpuscular conceptions in the context of chemical equilibrium and chemical kinetics, Chem. Educ. Res. Pract., 3 (2), 201-213.

[4] Cakmakci, G., Leach, J., and Donnelly, J., 2006, Students' ideas about reaction rate and its relationship with concentration or pressure, Int. J. Sci. Educ., 28 (15), 1795-1815.

[5] Azizoğlu, N., Alkan, M., and Geban, Ö., 2006, Undergraduate pre-service teachers' understandings and misconceptions of phase equilibrium, J. Chem. Educ., 83 (3), 947-953.

[6] Canpolat, N., 2006, Turkish undergraduates' misconceptions of evaporation, evaporation rate, and vapour pressure, Int. J. Sci. Educ., 28 (15), 17571770.
[7] Canpolat, N., Pinarbasi, T., and Sozbilir, M., 2006, Prospective teachers' misconceptions of vaporization and vapor pressure, J. Chem. Educ., 83 (8), 1237-1242.

[8] Sozbilir, M., and Bennett, J.M., 2006, Turkish prospective chemistry teachers' misunderstandings of enthalpy and spontaneity, Chem. Educ., 11 (5), 355-363.

[9] Carson, E.M., and Watson, J.R., 2002, Undergraduate students' understanding of entropy and Gibbs free energy, Univ. Chem. Educ., 6, 4-12.

[10] Bennett, J.M., and Sozbilir, M., 2007, A study of Turkish chemistry undergraduates' understanding of entropy, J. Chem. Educ., 84 (7), 1204-1208.

[11] Sozbilir, M., 2002, Turkish chemistry undergraduate students' misunderstandings of Gibbs free energy, Univ. Chem. Educ., 6, 73-83.

[12] Frailich, M., Kesner, M., and Hofstein, A., 2009, Enhancing students' understanding of the concept of chemical bonding by using activities provided on an interactive website, J. Res. Sci. Teach., 46 (3), 289-310.

[13] Pinarbasi, T., Sozbilir, M., and Canpolat, N., 2009, Prospective chemistry teachers' misconceptions about colligative properties: Boiling point elevation and freezing point depression, Chem. Educ. Res. Pract., 10 (4), 273-280.

[14] Tsaparlis, G., 2005, Non-algorithmic quantitative problem solving in university physical chemistry: A correlation study of the role of selective cognitive factors, Res. Sci. Technol. Educ., 23 (2), 125-148.

[15] Cakmakci, G., Leach, J., and Donnelly, J., 2006, Students' ideas about reaction rate and its relationship with concentration or pressure, Int. J. Sci. Educ., 28 (15), 1795-1815.

[16] Harle, M., and Towns, M., 2011, A review of spatial ability literature, its connection to chemistry, and implications for instruction, J. Chem. Educ., 88 (3), 351-360.

[17] Singer, S., and Smith, K.A., 2013, Discipline-based education research: Understanding and improving learning in undergraduate science and engineering, J. Eng. Educ., 102 (4), 468-471. 
[18] Taber, K.S., 2013, Revisiting the chemistry triplet: drawing upon the nature of chemical knowledge and the psychology of learning to inform chemistry education, Chem. Educ. Res. Pract., 14 (2), 156-168.

[19] Doymus, K., Karacop, A., and Simsek, U., 2010, Effects of jigsaw and animation techniques on students' understanding of concepts and subjects in electrochemistry, Educ. Technol. Res. Dev., 58 (6), 671-691.

[20] Regan, Á., Childs, P., and Hayes, S., 2011, The use of an intervention programme to improve undergraduate students' chemical knowledge and address their misconceptions, Chem. Educ. Res. Pract., 12 (2), 219-227.

[21] Cakir, M., 2008, Constructivist approaches to learning in science and their implications for science pedagogy: A literature review, Int. J. Environ. Sci. Educ., 3 (4), 193-206.

[22] Widarti, H.R., Permana, A., and Mulyani, S., 2016, Student misconception on redox titration (a challenge on the course implementation through cognitive dissonance based on the multiple representations), Indones. J. Sci. Educ., 5 (1), 56-62.

[23] Taber, K.S., 2001, Building the structural concept of chemistry: Some consideration from educational research, Chem. Educ. Res. Pract., 2 (2), 123-158.

[24] Tobin, K.G., 1994, "Constructivism as a Referent for Teaching and Learning" in The Practice of Constructivism in Science Education, $1^{\text {st }}$ Ed., Routledge, New York, 20.

[25] Wheatly, G.H., 1991, Constructivist perspectives on science and mathematics learning, Sci. Educ., 75 (1), 9-21.

[26] Michael, J., 2006, Where's the evidence that active learning works?, Adv. Physiol. Educ., 30 (4), 159-167.

[27] Park, S., and Oliver, J.S., 2007, Revisiting the conceptualization of Pedagogical Content Knowledge (PCK): PCK as a conceptual tool to understand teachers as professionals, Res. Sci. Educ., 38 (3), 261-284.

[28] Setyawati, A.A., 2009, Kimia - Mengkaji fenomena Alam untuk Kelas X SMA/MA, Pusat Perbukuan
Departemen Pendidikan Nasional, Jakarta, 131140.

[29] Permana, I., 2009, Memahami Kimia 1: SMA/MA untuk Kelas X Semester 1 dan 2, Pusat Perbukuan Departemen Pendidikan Nasional, Jakarta, 105112.

[30] Sunarya, Y., and Setiabudi, A., 2009, Mudah dan Aktif Belajar Kimia 1 untuk Kelas X SMA/MA, Pusat Perbukuan Departemen Pendidikan Nasional, Jakarta, 123-137.

[31] Utami, B., Saputro, A.N.C., Mahardiani, L., Yamtinah, S., and Mulyani, B., 2009, Kimia 1 untuk Kelas X SMA/MA, Pusat Perbukuan Departemen Pendidikan Nasional, Jakarta, 143-164.

[32] Harnanto, A., and Ruminten, 2009, Kimia 1 untuk Kelas X SMA/MA, Pusat Perbukuan Departemen Pendidikan Nasional, Jakarta, 131-142.

[33] Sudarmo, U., and Sariwati, E., 2015, Buku Siswa: Kimia untuk Kelas X SMA/MA (kelompok peminatan matematika dan ilmu alam) K2013, Erlangga, Jakarta.

[34] Purba, M., and Sarwiyati, E., 2016, Kimia 1 untuk Kelas X SMA/MA (kelompok peminatan matematika dan ilmu alam) K2013, Erlangga, Jakarta. p. 208-228.

[35] Muchtariadi, 2016, Kimia 1 Kelas X SMA (edisi revisi 2016), Yudhistira, Jakarta. 181-193.

[36] Watoni, H., Kurniawati, D., and Juniastri, M., 2016, Kimia untuk kelas X SMA/MA kelompok peminatan matematika dan ilmu-ilmu alam, Yrama Widya, Bandung.

[37] Hmelo-Silver, C.E., 2004, Problem-Based Learning: What and How Do Students Learn?, Educ. Psychol. Rev., 16 (3), 235-266.

[38] Özkaya, A.R., 2002, Conceptual difficulties experienced by prospective teachers in electrochemistry: Half-cell potential, cell potential, and chemical and electrochemical equilibrium in galvanic cells, J. Chem. Educ., 79 (6), 735-738.

[39] Mahaffy, P., 2004, The future shape of chemistry education, Chem. Educ. Res. Pract., 5 (3), 229-245.

[40] Garnet, P.J., and Treagust, D.F., 1992, Conceptual 
difficulties experienced by senior high school students of electrochemistry: Electric circuits and oxidation-reduction equations, J. Res. Sci. Teach., 29 (2), 121-142.

[41] Parkin, G., 2006, Valence, oxidation number, and formal charge: three related but fundamentally different concept, J. Chem. Educ., 83 (5), 791-799.

[42] Mann, J.B., Meek, T.L., and Allen, L.C., 2000, Configuration energies of the main group elements, J. Am. Chem. Soc., 122 (12), 2780-2783.

[43] Pauling, L., 1960, "The Partial Ionic Character of Covalent Bonds and the Relative Electro-negativity of Atoms" in The Nature of the Chemical Bond and the Structure of Molecules and Crystals: An Introduction to Modern Structural Chemistry, $3^{\text {rd }}$ Ed.,
Cornell University Press, New York, 64-107.

[44] Shehu, G., 2015, Two ideas of redox reaction: Misconceptions and their challenges in chemistry education, IOSR-JRME, 5 (1), 15-20.

[45] Nakleh, M.B., 1992, Why some student don't learn chemistry, J. Chem. Educ., 69 (3), 191-196.

[46] Basuki, R., Amanda, H., Bemis, R., Lisma, A., and Yusnaidar, Y., 2018, Incomplete explanation in determining oxidation number: A case study on chemistry program students, Indones. J. Sci. Educ., 7 (3), 333-340.

[47] Francisco, J.S., Nakleh, M.B., Nurrenbern, S.C., and Miller, M.L, 2002, Assessing student understanding of general chemistry with concept mapping, $J$. Chem. Educ., 79 (2), 248-257. 